\title{
The cultivation of the character values of early childhood by parent
}

\author{
Syuraini' ${ }^{1}$, Syafruddin Wahid ${ }^{2}$, Zahratul Azizah ${ }^{3}$, Alim Harun Pamungkas ${ }^{4}$ \\ ${ }^{1234}$ Universitas Negeri Padang, Padang - Indonesia, (syuraini@fip.unp.ac.id)
}

\begin{abstract}
This research aims to know the description of model parent implemented character education at home. Research methods using R development model D with \& ADDIE. The population of the research was the parents in Kindergarten of Aisyiyah at Padang city. Sampling techniques using cluster random sampling that is the center of the city, the suburbs and the city centre and suburbs. The instruments used are a test of the validity of using with cheklist construct and content validity. The results showed that generally how committed parents in educating children character is by way of conditioning, then followed by the rules. While other ways such as giving advice, and less is done by the parents. It is very possible because more parents emulating what has been done to his parents during this time.
\end{abstract}

Keywords: cultivating, character values, parents Padang.

\section{Introduction}

The good guys are the ones that have character values in accordance with the applicable rules and norms. Because, if the applicable rules and norms had already been followed properly will certainly created a good life anyway. Khaidir \& Prayitno (2010) stated that the desired life is a life of straight roads follow the norms of values and norms that are oriented towards truth and excellency. People who are in daily is well-behaved, intelligent characters usually have. The character is the behavior of someone who's been fused in him and become their personality in everyday life. In order for a person to have a good personality needed a character education efforts fostering, guiding and directing the children to be good people, ethical sublime and noble character. So overall it was created then need to create the learning that can arouse children's hearts and fun for children.

Accordance with Maryatun (2011) the character would become the soul of the child, if the delivery is fun and challenging to studied by children, both the giving of knowledge and the cultivation of the behavior. Character education can be done in a variety of environments and types of education. All types of environmental education is in practice cannot be separated from one another because between schools, families and communities have the connectedness very closely.

Surbakti (2012) stated that togetherness within the responsibility of education aims to: (1) helping educators to (teacher/ parents/ another educator), developing children so that later when they become individuals who have quality and integrity; (2) play a role towards education and the development of reliable intellect intelligence; (3) supervise and control the child's behavior and thinking about the future so that the individual would become successful. NNS (2013) add that education given by 
parents to their children is an education that will always go hand in hand with the formation of the personality of the child.

Achievement of educational results optimally requires good coaching from these three types of educational environment in each line and level of education ranging from basic education, secondary education, further education pre-existent a school or early childhood education. Early childhood for a lot more life in the family with his parents, therefore in the early childhood education parents should be more involved. Mulyatiningsih (2010) stated that the family is first obtained learning environment of the child and would be a strong foundation to form the adult character after.

Sujiono stated that (2009) an early age is the age of a very decisive in the formation of a child's character and personality. Permono (2013) stated that a very strategic role in the optimization of education early childhood is the role of parents. Conditioning is accompanied by example and reinforced with the cultivation of the values that underlie will gradually establish the culture and develop a relationship with God.

To achieve the goal of early childhood education, namely the construction of the growing flower children, the creation of intelligent character values should be done jointly between educators in preschool institutions with parents at home. With the cooperation expected in educating children act of harmony, so that the child does not become confused as to which both received and which ones are not good. Even if the collaboration is already well underway already certain that a child's personality will be better because children go anywhere he gets the same norms and cannot be avoided any longer.

If the current conditions observed between parents and teachers is not yet in line in educating children. Teachers carry out education in educational institutions according to the curriculum with the methods and techniques that are studied and according to early childhood learning, while the parents carry out education in accordance with the ways that generally obtained hereditary so inequalities in education. In fact the teacher must have the ability to establish cooperation, either individually or in groups with parents (Sanjaya, 2008: 200). This means that teachers have to get together with parents in educating children. Teachers should have a program that can bring the parents in togetherness instill the values of character in children. The teacher should take the initiative to establish a program to involve parents more.

The fact shows that many parents are not getting a call from a teacher to flower children grow together to optimize. Whereas according to Yamin \& Sanan (2010: 323) "collaboration between teachers, students and parents is a must "mean between parents and teachers must always carry out the efforts of the development potential of children together.

On the other hand many parents preoccupied with work to earn a living to meet basic needs, such as food, clothing, and other necessities. They do not have enough time to think about how to improve their child's development (Ormrod, 2009). This can be evidenced from the meeting held in the presechool education and undesirable by most parents.

The successful education instilling the values of character is inseparable from the assistance and full support from parents. No matter how good the program drawn up by the institution, but in practice often encounter difficulties if parents do not support the implementation of the program. The main support is desperately needed the participation of parents in the House in applying values to characters. 


\section{Method}

This study was designed as a research development. This research used a quantitative approach. The quantitative approach used in the initial collection of data i.e. data about the character education has been done during this time parents against children at home and a data character education school teachers conducted before this model was developed. A quantitative approach is also used to view the practicality and effectiveness of the model which was developed after a tackle in the process of testing the model.

The population of this research are all parents and school teachers in kindergartens ' Aisyiyah who was in 30 kindergartens in Padang city. Kindergarten is scattered all over the town there are in the Padang city with the number of teachers of 210 people. The research sample is taken using multi stage random sampling with the category of the city centre, the edge of the city, and between the city centre and suburbs. Each cluster is taken one (1) fruit kindergarten. Kindergarten amount thus being sampled is as much as 3 pieces.

The instruments used in the data collection is to test the validity of using with cheklist construct and content validity. Construct validity is carried out with the aim to see whether the instruments used already have good language and easily understood by respondents as well as in accordance with the research objectives. While the content validity of the indicators to see if all of the variables included in the research instrument, so that the research be complete.

\section{Results and Discussion}

Education parents conducted in the construction of the characters were very diverse. The type of the values that instilled also has many variations. Basically the parents wanted his son to be a person who has good manners, useful to the homeland and the nation. Therefore parents dress with the most to instill the values of the characters. However, sometimes the way incompatible with science education. This research tries to uncover ways that parents used in instilling the values of character to early childhood that includes religious values, honesty, discipline, tolerance, self-reliance, please help and responsibility. Table 3 below illustrates the results of character education is done by parents at home.

Table 3. An overview of the implemented character education parents at home

\begin{tabular}{clcccc}
\hline Number. & $\begin{array}{c}\text { The value of a character } \\
\text { that is implanted }\end{array}$ & \multicolumn{4}{c}{ Methods } \\
\cline { 3 - 6 } & & $\begin{array}{c}\text { Modeling } \\
\%\end{array}$ & $\begin{array}{c}\text { Conditioning } \\
\%\end{array}$ & $\begin{array}{c}\text { Rule } \\
\%\end{array}$ & $\begin{array}{c}\text { Instruction } \\
\%\end{array}$ \\
\hline 1. & Religious & 13,67 & $\mathbf{6 5 , 2 6}$ & 1,31 & 19,76 \\
2. & Honesty & 19,85 & $\mathbf{4 8 , 1 4}$ & 13,90 & 18,11 \\
3. & Discipline & 8,71 & 33,55 & $\mathbf{4 2 , 7 0}$ & 15,04 \\
4. & Tolerance & 22,27 & $\mathbf{6 0 , 0 8}$ & 5,46 & 12,19 \\
5. & Standalone & 7,29 & $\mathbf{7 3 , 1 7}$ & 12,67 & 6,87 \\
6. & Help & 19,33 & $\mathbf{6 5 , 1 3}$ & 3,36 & 12,18 \\
7. & The responsibility & 5,06 & $\mathbf{4 4 , 3 0}$ & 29,54 & 21,10 \\
& Average & 13,74 & $\mathbf{5 6 , 6 6}$ & 15,56 & 15,04 \\
\hline
\end{tabular}

Table 3 illustrates the ways that people use in implanting niali character values to children. Seen that conditioning is the most widely performed by parents, i.e. as much as $56.66 \%$. While the minimal model, rules and orders have a much smaller amount of conditioning. This means that parents already doing conditioning in instilling the values of the characters on his son. While the modeling has the lowest percentage of ie $13.74 \%$. Can thus be taken to mean that parents generally have instilled values character by way of conditioning. However, by way of giving is still very little in 
terms of parents should be more use of modeling in instilling the values of the characters on his son. If seen from the character values that are cultivated, then none is dominated by lead by example. In more clearly can be seen in Figure 3.

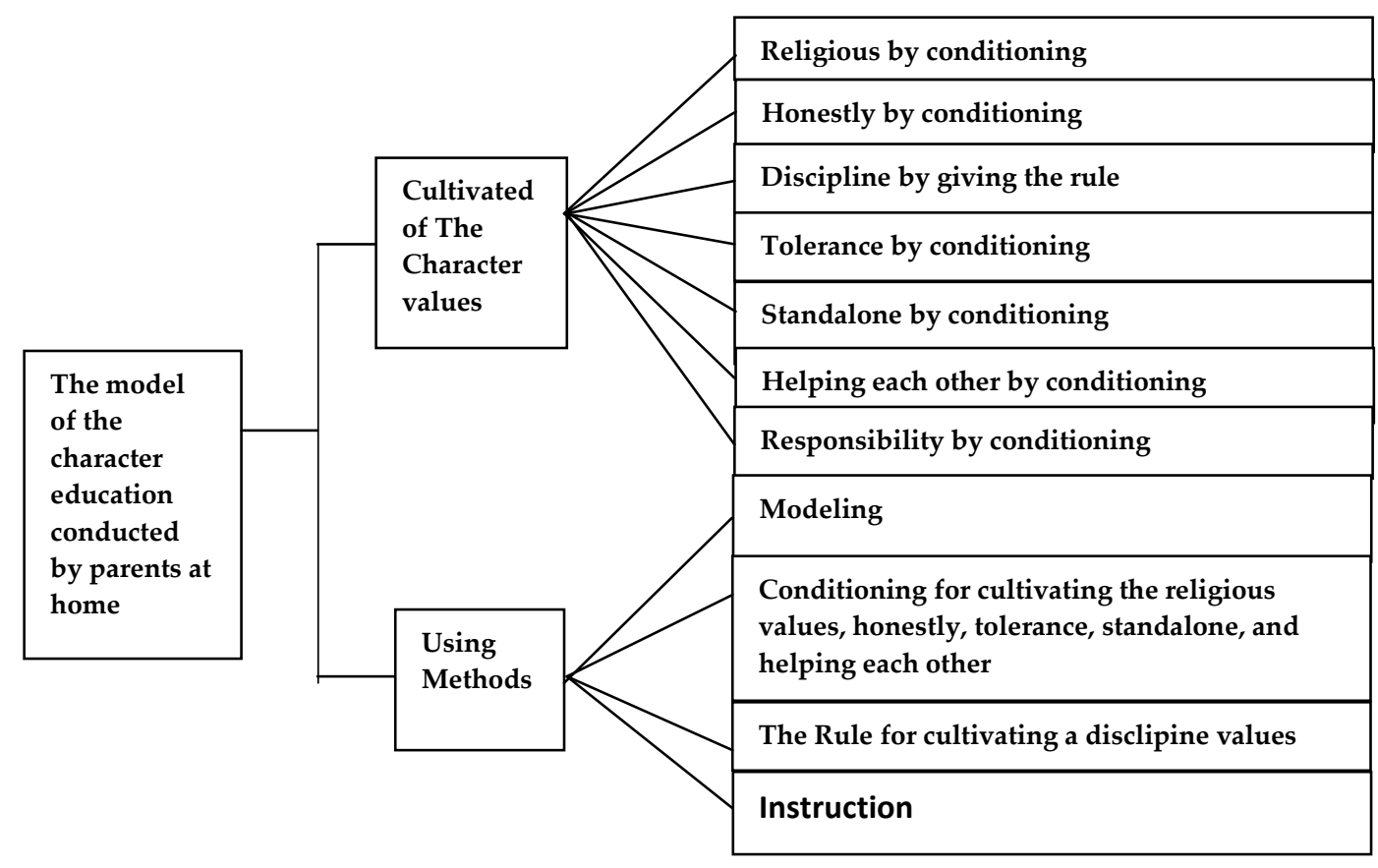

Figure 3. The Model of Characer Education Conducted by Parents at home

The results showed that the largest percentage of the picture of the character education implemented a parent at home is by way of conditioning. Parents carry out education on his son based on conditioning but conditioning is done does not yet have a clear pattern. It is very possible because parents usually have the habit received hereditary from his parents and at the question of having children then automatically copied and handed down on his son.

In this kind of thing parents will be coloring her son's behaviour even determine the character of his son. Parents habits and rising motion can shape the behavior of children. According to Maryatun (2011) characters must be conditioned in all aspects of children's lives through awarding examples which later will bear behavior, not just taught in theory and worksheets. Surbakti (2012) suggests some things that can affect a child's behavior of which through speech, manners and behaviour of parents. If parents get used to good deeds, then the child's behaviour would be good also so vice versa if parents do not get used to good deeds, then the child will not be well behaved.

Aside from such conditioning tendencies that do parents also lead by example and much-needed rules. Important things to note are the parents lead by example and by administering the rules against children will be able to form a child being disciplined and responsible. It's just, this is rarely done by parents. A minimal model or example would be emulated by children and parents can be the best model for his son. Surbakti (2012) raised the role of parents as the impersonation model for children for example in act, behave, behave, speak, activity.

From the conditions that is found may need to watch out for "do parents really have done the conditioning in accordance with the child's development?". Of course it is not possible because the parents have different educational backgrounds, so knowledge of educating children also vary. Therefore, required a model that can accomodate the ability of parents in educating children, so get 
better results for the foreseeable future. Parents need to be built through educational institutions for optimizing child development (Syur'aini, 2013). This is a container referred to in parenting activities.

\section{Conclussions}

Based on the findings and discussion as has been expressed can be concluded that the description of the model of the character education conducted a parent at home against the Cubs was more focused on conditioning. Conditioning is done to inculcate religious character, honesty, tolerance, self help, please help, and responsibility. While the cultivation of the values parents use the rules in the discipline of cultivation occurring.

\section{References}

Khaidir, Avriva \& Prayitno. (2010). Model Pendidikan Karakter Cerdas. Universitas Negeri Padang. Maryatun, Ika Budi. (2011). Peran Pendidik PAUD dalam membangun Karakter Anak. Jurnal Pendidikan Anak Vol. 5 No. 1

Mulyatiningsih, Endang. (2010). Analisis Model-model Pendidikan Karakter untuk Usia Anak-anak, Remaja dan Dewasa. Universitas Negeri Yogyakarta

NNS, Siregar. (2013). Persepsi Orangtua terhadap Pentingnya Pendidikan bagi Anak. Jurnal Ilmu Pemerintahan dan Sosial Politik. Vol. 1 Hal 11-27

Ormrod, Jeanne Ellis. (2009). Psikologi Pendidikan Membantu Siswa Tumbuh dan Berkembang. Terjemahan oleh Rikard Rahmat (Ed). (2009). Surabaya: Erlangga.

Permono, H. (2013). Peran Orang Tua dalam Optimalisasi Tumbuh Kembang Anak untuk Membangun Karakter Anak Usia Dini. Prosiding Seminar Nasional Parenting, 34-47.

Sanjaya, Wina. (2009). Kurikulum dan Pembelajaran: Teori dan Praktik Pengembangan Kurikulum Tingkat Satuan Pendidikan (KTSP).Jakarta: Kencana Prenada Media Group.

Sujiono, Yuliani Nurani. Konsep Dasar Pendidikan Anak Usia Dini. Jakarta: Indeks.

Surbakti, E.B. (2012). Parenting Anak-Anak. Jakarta: Gramedia.

Syur'aini. (2013). Program Parenting Sebagai Wadah Pembinaan Bagi Orangtua Murid di Lembaga Pendidikan Anak Usia Dini. Kolekium Jurnal pendidikan Luar Sekolah. Volume I, Nomor 1, Oktober 2013.

Yamin, Martinis \& Jamilah Sabri Sanan. (2010). Panduan Pendidikan Anak Usia Dini. Jakarta: Gaung Persada Press. 